\title{
The ECOLOGICAL AND ECONOMIC CONSEQUENCES OF CHANGING LAND USE IN THE SOUTHERN DRAKENSBERG Grasslands, South AFrica
}

\author{
Jane K. Turpie \\ Percy FitzPatrick Institute, University of Cape Town \\ Tim O'Connor \\ Centre for African Ecology, University of the Witwatersrand \\ Anthony Mills \\ Department of Soil Science, Stellenbosch University \\ Hamish Robertson \\ Iziko South African Museum, Cape Town
}

\begin{abstract}
The grassland biome of the southern Drakensberg region of South Africa is characterised by a relatively rich floral biodiversity, including a high level of endemics. Land use in the area was traditionally dominated by livestock ranching based mainly on indigenous grassland that conserved biodiversity to some degree. Currently, however, market demands and risk factors are shifting land use in the area to a matrix of beef, cropping, dairy and, in particular, plantation forestry. A spreadsheet model was constructed to assist understanding of how expected land-use conversion will in all likelihood influence the biodiversity, and, consequently, the total economic value (TEV) of the area. Six scenarios of increasing dairy and forestry intensification were modelled, incorporating biophysical and legal constraints to development. Results indicate that enhanced development is likely to have significant negative biodiversity impacts, including the reduction of the alpha diversity of the indigenous plants in the region, a diminished local invertebrate diversity and an increase in invasions. This could also jeopardise the long-term survival of the rare Wattled Crane and Oribi. Furthermore, while the direct-use value derived from agriculture and forestry increases with increasing development, its negative influence on the indirect value of water runoff, by far the greatest value of the area, is sufficient to potentially offset the benefits. Other major direct-use, indirect-use, option and existence values are also considered.
\end{abstract}

JEL Q32, 57

\section{1}

\section{Introduction}

Biodiversity conservation is of global concern, with increasing recognition of the importance of biodiversity for the sound functioning of ecosystems that ensure the provision of goods and services to society. Concern is heightened for regions subject to accelerated transformation of indigenous systems, especially where such systems are well endowed with biodiversity, including endemics and threatened species. One approach to assessing the vulnerability of biodiversity to transformation is an economic evaluation that compares the contribution of an indigenous system with that of the transformed systems that may replace it.

The southern Drakensberg grasslands provide an ideal opportunity for assessing the economic consequences of biodiversity loss resulting from land transformation. Less than two per cent of the Grassland Biome in South Africa, 
characterised by a relatively high level of endemism, is formally protected (O'Connor \& Bredenkamp, 1997; Rebelo, 1997). Key goods and services provided by the indigenous biota of the region include support of livestock farming, regulation of catchment water supply, tourism opportunities and the provision of natural foodstuffs, indigenous medicines and building materials. Regulation of water supply is particularly important in a seasonal rainfall area for maintaining flows throughout the year, thus ensuring the continued output of goods and services from downstream aquatic ecosystems. The southern Drakensberg region is sought after for agricultural and timber production owing to a high mean annual precipitation (MAP) of about $900 \mathrm{~mm}$ in an otherwise semi-arid country (MAP of $450 \mathrm{~mm}$; Schulze, 1997).

The area was originally settled by indigenous peoples under communal tenure from the 1850 s, and then opened to settlers under private tenure ("commercial") about a century ago. The traditional commercial production was extensive livestock ranching (beef and sheep), whereas communal areas had livestock and cropping. Ranching was based mainly on indigenous grassland and conserved biodiversity to a degree. Whereas communal areas are in less use today, indigenous grasslands on commercial farms have, for the past 50 years, continued to come under threat from transformation to exotic vegetation used for production purposes. Stock theft and declining output prices for livestock have driven changes to afforestation, cropping, dairy extensification and intensification based mainly on winter pastures and the required irrigation dams, as well as tourism based mainly on trout fishing.

These trends are of concern for biodiversity conservation. Whereas extensive livestock ranching maintained grasslands, transformed landscapes are expected to impact negatively on biodiversity and ecosystem functioning, especially water supply, as well as promoting the spread of alien plants. While not all of the grassland area can be transformed because of biophysical and legal limitations, the ecological and economic impacts of different levels of transformation are not known. We address the macro-scale transformation of grasslands and its impact on biodiversity, ecosystem functioning and the services provided to society. This study attempts to address the following key questions for a defined area within the southern Drakensberg:

1. What is the current pattern of land use, and the value of agricultural production?

2. How have current land-use patterns affected biodiversity and ecosystem services?

3. What levels of transformation are possible over the next 20 years?

4. What are the biodiversity consequences of alternative scenarios for future transformation?

5. What are the economic consequences (financial and economic, including ecosystem goods and services) of alternative scenarios for future transformation?

\section{2}

\section{Study area}

The Underberg Magisterial District, situated in the southern Drakensberg (Figure 1), was selected as a suitable area because relevant data are available, mainly for magisterial districts. The Underberg district, approximately 195 000 ha in area, extends from the Drakensberg escarpment eastwards to undulating midlands. The escarpment falls within the UkhahlambaDrakensberg Park, whereas this study is concerned with the remaining 100000 ha of predominantly agricultural land at lower altitudes. Approximately 1400 ha of this land are protected in the Coleford and Himeville Nature Reserves, while the remainder is used for livestock ranching, dairy, cropping and timber. Natural grassland is dominant at present. 


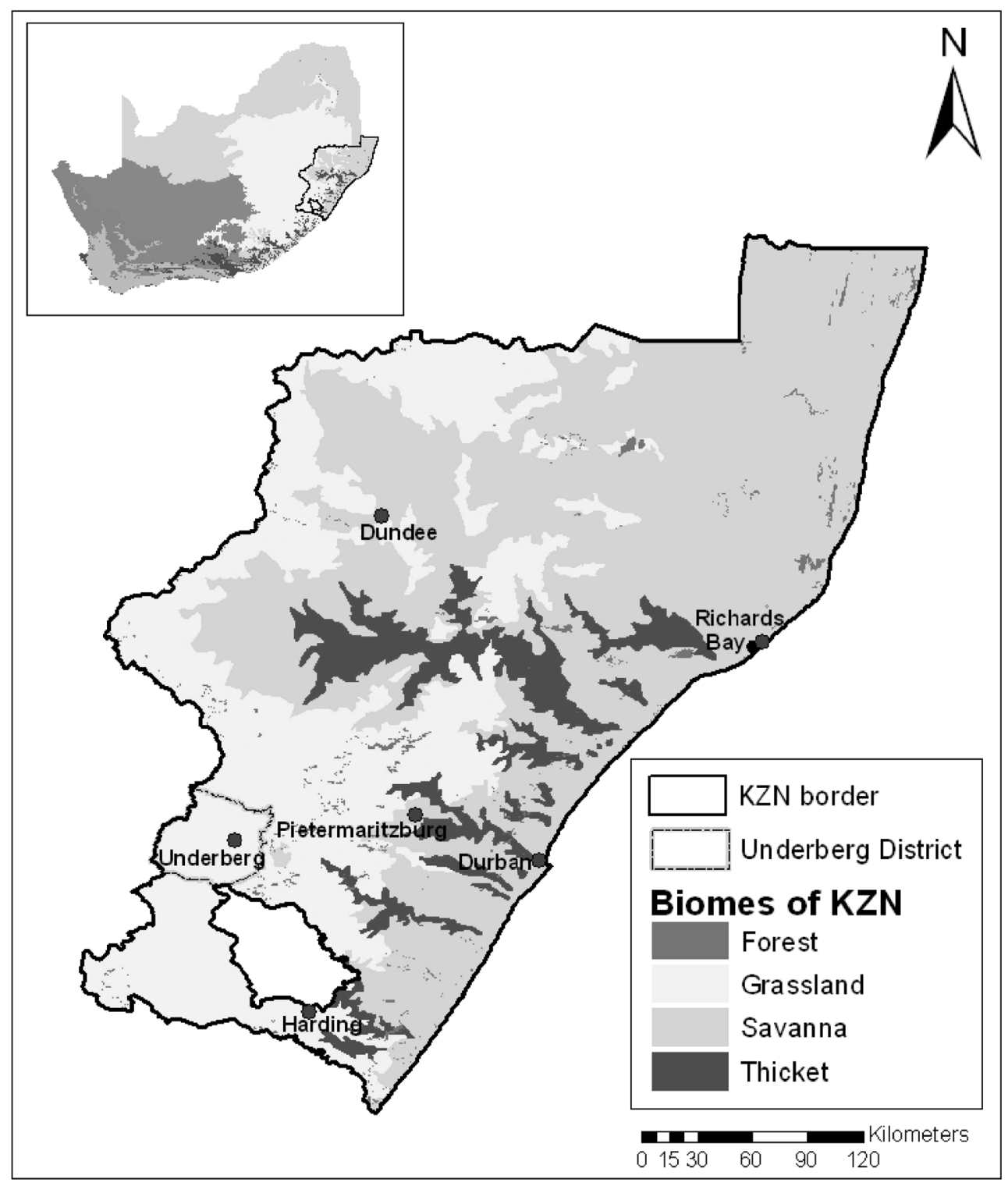

Figure 1

The position of the Underberg Magisterial District in KwaZulu-Natal in relation to the grassland biome

3

\section{General approach and scenarios}

The broad approach was to compare the existing situation with plausible scenarios of future land use in terms of biodiversity and total economic value relating to ecosystem functioning. The ecological state of the region is indexed for selected components (e.g. plant species richness) and indicator species (e.g. Red Data or economically important species). The total economic value of natural systems is typically divided into direct-use values, indirect-use values, option value and existence value. The direct-use values considered include agricultural production, natural resource harvesting and 
natural resource-based tourism. The costs of controlling invasive alien plants are also considered, as their removal by landowners is now mandatory. Indirect-use values are those generated beyond the study area (e.g. carbon sequestration, water provision). Option value is the potential future use value of an area, and is impossible to predict in full. In this case we consider the option to use existing plant and animal resources at sustainable levels. Existence value is the satisfaction gained by the general public on account of the existence of certain characteristics of an area and reflects society's willingness to pay for retaining these characteristics.

The status quo was described for 2001, based on collation and collection of available data, modelling (e.g. runoff) and, where necessary, proxy data from comparable areas. Translation of information into an economic perspective at landscape level in order to provide an overview of biodiversity and ecosystem health under different land-use scenarios was achieved through an expert approach. Values are expressed in 2007 rands.

The following six possible scenarios of future land use were examined, as well as a scenario representing land use prior to transformation as a reference state for ecosystem health.

1. Extensive grazing: As if no transformation had taken place until the base year (2001) and the area was still under extensive livestock farming;

2. Status quo: Land use during the base year (2001);

3. Forestry permits fully utilised: as above but with all forestry permits (as defined in 2003) having been fully utilised.

4. Current forestry permits plus maximum dairy: as above, but with cultivation of remaining grassland areas suitable for pasture and feed crops.

5. Maximum forestry permits plus maximum dairy: as above, but with forestry expanded to the permissible level, taking biophysical and legal constraints into consideration.

6. Maximum afforestation: an extreme scenario in which there is afforestation of all areas outside water courses with forestry potential.
Ecological and economic data were converted into units per hectare for different land-use types and, where relevant, the overall area effect (e.g. animal populations) was taken into account. Scenarios were analysed using a spreadsheet model.

\section{4}

\section{Data sources and analytical techniques}

\subsection{Estimating current land use}

Data on past and present land use were obtained from agricultural census data for 1983, 1988 and 1993) (DoA 1987, 1992, 1997) and existing GIS data. Land use was established on the basis of the combined 2001 land cover, detailed land use and forestry data, guided by local knowledge of the area. All area data were calculated from an Albers Equal Area Conic projection set to a Clarke 1880 spheroid. Areas calculated using GIS data showed a one per cent deviation from catchment areas given by Gush et al. (2002a) and WRC data (Le Maitre et al. 1996), which was considered insignificant.

\subsection{Estimating the limits to afforestation}

The maximum area of afforestation that would occur under current legal and biophysical constraints (Scenario 5) was estimated, using a combination of water-yield modelling and GIS analysis. The maximum area that could be permitted for afforestation by the Department of Water Affairs and Forestry (DWAF) under current legislation, irrespective of biophysical or other limitations, was estimated using a stream flow reduction activity (SFRA) model (Gush et al., 2002a,b). This model estimates runoff reduction in individual catchments and is currently used by DWAF for allocating licences (Chris Davel, DWAF, pers. comm). The model calculates runoff reductions in terms of both total and low flows. The potential limit to afforestation as a result of SFRA licensing is based on a maximum allowable runoff reduction of 10 per cent of MAR (DWAF, 1999).

The model was run for each of the 13 quaternary catchments occurring fully or partially within the Underberg magisterial 
district. Modelling was used to arrive at runoff reductions in total and low flow that approximated a 10 per cent reduction in baseline flows for these two parameters, resulting in a maximum (total flow) and minimum (low flow) estimate. These baseline flows are based on the estimated flow under each of the Acock's vegetation types occurring in the catchment (Gush et al., 2002a, b). The magnitude of these baseline flows, specifically within the Underberg district, were calculated and used to investigate overall reduction, as most catchments extended to varying degrees beyond the borders of the district. The permitted area of afforestation within each catchment in the Underberg district was assumed to be proportional to the catchment area occurring in the district. This estimate was further refined according to other legal and biophysical limits. Owing to lack of information on the exact species to be planted under various scenarios, the maximum runoff impact, regardless of species, was used, as runoff reductions can vary between species (Scott \& Smith, 1997, Scott et al., 1998). Runoff calculations were based on DWAF methodology (Appendix 1).

The maximum afforestation potential of the area, irrespective of legal constraints (Scenario 6), was estimated using Fairbanks \& Smith's (1995) forestry potential data, which consider only an ecological limit to afforestation. Further "no go" areas were excluded according to DWAF guidelines for afforestation permits (DWAF, 1999). These include designated protected areas, dams, wetlands, indigenous forests and settlements. Eroded areas were assumed to be unsuitable for planting.

\subsection{Biodiversity data and extrapolation to scenarios}

Studies on the biodiversity and ecology of different land uses in the study area included plant diversity (O'Connor, 2003a), distribution and abundance of alien invasive plants (O'Connor, 2003b), plant biomass (O'Connor, in press), medicinal plant populations (O'Connor, 2004) and invertebrate diversity (Wildy, 2003). This also included ant diversity (Robertson \& van Noort, 2003), nutrient stocks (O'Connor
\& Mills, 2003), wetland functioning (Kotze \& O’Connor, 2003), soil properties (Mills, 2003), rangeland dynamics (Short et al., 2003) and antelope population dynamics (O'Connor \& Kruger, 2003).

Using the findings of these studies, a set of indices was identified for assessing the implications for biodiversity of different scenarios of land-use change. Choice of indices sought to reflect a broad spectrum of plant and animal taxa differing in their ecological characteristics, as well as taxa for which the area is of particular importance for conservation. Indices included species richness of indigenous plants or of alien plants, abundance of American Bramble, the most ubiquitous alien plant, number of red data plant species in the regional pool (ScottShaw, 1999), species richness of selected invertebrate groups (ants, bees, ichneumonid wasps, aculeate wasps, orthopterans, butterflies, staphylinid beetles, carabid beetles) (Robertson \& van Noort, 2003; Wildy, 2003). Abundance of Streblognathus peetersi, a large conspicuous ant associated with grassland and considered particularly vulnerable to the effects of grassland fragmentation, is included separately as an indicator. Reedbuck (Redunca arundinum), mountain reedbuck (Redunca fulvorufula), rhebok (Pelea capreolus) and oribi (Ourebia ourebia) were indexed according to their population density. Data on two red data bird species, Wattled Crane (Grus carunculatus) and Crowned Crane (Balearica regulorum), were obtained from the Crane Foundation. For the scenario analyses, the numbers of pairs of Wattled Crane were estimated on the basis of the predicted area of dams and the predicted proportion of dams that would be surrounded by grassland. Total numbers of Crowned Crane were estimated on the basis of the area of maize fields and grassland.

\subsection{Ecosystem processes}

Land uses were assessed for their ability to deliver ecosystem services like carbon sequestration, and their impact on catchment water supply. 


\subsection{Carbon sequestration}

The total biomass of forest plantations is higher than that of the montane grasslands they replace, resulting in a higher storage of carbon (C). C density in montane grassland is estimated to be about $6 \mathrm{mg}$ per ha (Christie \& Scholes, 1995). A minimum life cycle of 20 years is considered to be a permanent sink of carbon for C-containing products (IPCC/OECD, 1994). For this reason, biomass carbon was considered only for forestry but not other crops. A static method to calculate $\mathrm{C}$ storage was used based on peak carbon densities at maturity or the mean carbon storage over the full rotation (Christie \& Scholes, 1995).

Soil C and N stocks to a depth of $50 \mathrm{~cm}$ were sampled (Mills, 2003). Carbon stocks in each land use were calculated by summing the mean soil, litter, aboveground biomass and belowground biomass carbon. Nutrient stocks within soil organic matter were estimated according to ratios of $1000(\mathrm{C}): 100(\mathrm{~N})$ : $10(\mathrm{P})$ : $10(\mathrm{~S}): 1(\mathrm{Zn})$. In order to obtain an annual rate of sequestration or loss, it was assumed that the accumulation or loss of soil carbon stocks estimated in the samples had taken place over a 20-year period for each land use, and net gains or losses of $\mathrm{C}$ were thus divided by 20 .

\subsection{Water supply and losses}

The SFRA model was used to estimate changes in runoff under the different degrees of afforestation. Changes in runoff from plantations had to be estimated for the total area separately within each quaternary catchment, and aggregated for the district. Evaporative losses from dams were estimated to be 1686 $\mathrm{mm}$ per year and irrigation losses were assumed to be 10 per cent of the total water used for irrigation.

\subsection{Soil losses}

Few studies have quantified soil loss for different land uses. It is estimated that about four tons of soil are lost per ha per year from areas under maize (D. Leighme, Cedara, pers. comm.). Ryegrass pastures are assumed to incur similar losses because of the way ryegrass is cultivated, whereas losses from Kikuyu and Eragrostis pastures are assumed to be negligible. Soil losses from plantation forestry are highly variable, and were estimated to be in the order of 1 ton per ha per year (Mills, 2003). Dairy farming crops and pastures were assumed to be typically comprised of about 40 per cent maize, 40 per cent ryegrass, 10 per cent kikuyu and 10 per cent Eragrostis.

\subsection{Economic activities and values}

\subsubsection{Agricultural production}

The economic benefits of each land use were estimated from existing data on the typical gross margins of different farming enterprises in the study area, and from interviews on net farm income with a small sample of landowners. Data (gross margin level) were sourced from the government-published enterprise budgets for crops, pasture and livestock (KwaZulu-Natal Department of Agriculture and Environment Affairs, Division of Agricultural Economics), Finrec study group results, and Forestry Economics Services.

Production and resource information was collected from six farmers (including beef, dairy, seed potato, timber and game farmers) by means of face-to-face interviews (2-3 hours), with a structured questionnaire. The questionnaire addressed three components: farming activities, including types and numbers of livestock and their stock management and grazing programmes, description of crops and pastures, timber activities and tourism activities; costs, including capital costs, maintenance, livestock production, crop and pasture production, machinery and vehicle costs, overhead costs, labour costs, and income, categorised as livestock, crop or timber income. Net farm income was calculated at both farm and enterprise level.

Value added to the national economy was calculated for each enterprise on a per ha basis as the difference between the value of the output and the value of all inputs purchased from outside the enterprise (Gittinger, 1982). The capital and labour attached to the enterprise are considered internal inputs. In the case of forestry, value added per ha was estimated based on Hassan (2000). 


\subsubsection{Tourism and recreation}

Data on accommodation establishments and prices was obtained from the tourism office in Underberg. Occupancy rates were obtained from Metroplan (2001). The total net value of tourism was taken as 25 per cent of the total estimated turnover in the area. On account of the lack of studies on the impact of landuse changes on tourism demand, tourism was assumed to be affected in inverse proportion to the area of plantation forestry. This assumption was based on the fact that most tourism in the area is nature-based.

The estimated turnover from trout fishing in rivers and dams in the southern Drakensberg is about R54 million ( $\mathrm{J}$. Alletson, FOSAF, pers. comm. 2007 rands), a quarter of which would be attributed to the Underberg district. This would equate with about 7500 fishing visits per year in comparison with the Crocodile River catchment, where fishers manage an average of 10.4 visits per year, with a total expenditure of almost R19 000 per annum (J. Alletson, pers. comm. 2007 rands). Trout fishing has led to the growth of a hospitality industry.

\subsubsection{Harvested natural resources}

Farm labourers harvest medicinal plants, thatching grass and firewood on private grasslands, the amount and value of which was estimated according to harvests on nearby comparable communal lands (Nathan Associates, 2001) and expressed in 2007 rands. One hundred $\mathrm{kg} \mathrm{ha}^{-1}$ of medicinal plants (bulbs and herbs) were estimated to be available, of which $20 \mathrm{~kg}$ $\mathrm{ha}^{-1} \mathrm{yr}^{-1}$ could be harvested on a sustainable basis at a value of $\mathrm{R} 9.4 \mathrm{~kg}^{-1}$. Hyparrhenia thatching grass is patchily distributed across the landscape, providing on average $20 \mathrm{~kg} \mathrm{ha}^{-1}$ at a value of $\mathrm{R} 4.40 \mathrm{~kg}^{-1}$. Firewood for cooking and heating is provided by long-standing groves of wattle (Acacia mearnsii, A. dealbata), which cover 5 per cent of grazing lands. Consumption per household was estimated at 7 tonnes $\mathrm{yr}^{-1}$ at a value of $\mathrm{R} 0.34 \mathrm{~kg}^{1}$. The amount harvested used in scenario calculations was conservatively set at half these values.

\subsubsection{Water supply}

A key indirect benefit of montane grasslands is the regulation of water, in which baseline flows are maintained during winter. Afforestation utilises some of the water that would otherwise form catchment runoff. This change in flow can be valued in terms of loss of water available for direct use in economic activities. The accepted norm for valuing water in SA is an opportunity-cost approach (e.g. Hassan, 2000; CSIR, 2001; King \& Crafford, 2001; De Wit et al., 2003; Conningarth Consultants, 2003; van Wilgen et al., 2004). Based on Hassan (2000), estimated water losses from forestry are in the order of R373 per ha per year (2007 rands), which amounted to about a quarter of the value added in forestry. The average value added (VAD) for water used in South Africa is R33.5/ $\mathrm{m}^{3}$ (King \& Crafford, 2001, in 2007 rands). Country wide, 19 per cent of mean annual runoff (MAR) is used for industry and irrigation (CSIR, 2001), which works out to an average VAD of R6.37/ $\mathrm{m}^{3}$ of total MAR. For the catchment management area in which the study area is situated, 6.9 per cent of MAR is used for industry and irrigation (CSIR, 2001), and average (not marginal) VAD is R2.32 per $\mathrm{m}^{3}$ of MAR. It is assumed that the average value of water is a close approximation of the marginal value, as the marginal value of water is unknown (CSIR, 2001). The average value was applied to total flows estimated under the different land-use scenarios.

\subsubsection{Carbon sequestration}

The economic value of carbon sequestration lies in the belief that it offsets increased industrial output of $\mathrm{CO}_{2}$ into the atmosphere. Most studies tend to use global value estimates (global average $=\$ 5.24$ per ton) from climate change models (Nordhaus, 1994). Applying the Nordhaus estimate of 1 per cent of GDP as the climate-change damage cost, this is equivalent to $\$ 9$ per ton (Hassan, 2000). Recent estimates of climate-change damage costs suggest that it is more in the range of 1.5 per cent (Turpie et al., 2004). Taking into account the fact that carbon contributes about 60 per cent of total greenhouse gas emissions in South Africa (Rowlands, 1996, Scholes \& van der Merwe, $1995)$, this leads to an estimated value of $\$ 8$ per ton $(\$ 1 \sim \mathrm{R} 7$ in 2007). 


\subsubsection{Soil losses}

Soil losses were costed using an estimated replacement cost of R80 per ton, based on rough prices of topsoil loads.

\subsubsection{Alien clearing}

Rubus cuneifolius is a category 1 weed, for which control is mandatory under the Conservation of Agricultural Resources Act. Its level of infestation ranged from 5 per cent cover for conserved grassland areas to 43 per cent cover for plantations (L. Breebaart, Conservation Farming Project, in litt.). Bramble is controlled manually by poisoning at a cost of about R 4000 per ha in the first year, decreasing to an annual maintenance cost of R400 per ha by the fifth year (W. Pitchford, ex Working for Water, pers. comm., in 2007 rands). Average annual costs of clearing, assuming that clearing activities would be spread evenly over the catchment in terms of their progress along a twenty-year treatment period, were estimated as R824 per ha per year.

\subsubsection{Option and existence value}

A partial estimate of option value was made as being the immediate income that could be derived from sustainable harvesting of natural resources including plants and animals. For plants, this value was based on harvests taken elsewhere, minus the amount estimated to be harvested in the study area (see above). In addition, the potential for flower harvesting was taken into consideration, with estimates of sustainable yield supplied by botanists on the basis of professional opinion. Typical prices per stem were applied. The value of hunting was conservatively estimated on the basis of a 15 per cent offtake of reedbuck at R800 per animal (which includes associated expenditure like accommodation).

Existence value is measured using costly stated-preference survey techniques, and was beyond the scope of this study. However, the average willingness to pay for South African biodiversity as a whole (Turpie, 2003) was applied to the area of natural habitat remaining under each scenario in order to arrive at a conservative estimate of existence value.

\section{5}

\section{Description of the status quo}

\subsection{Land use}

Areas under different land-use categories are summarised in Table 1. In its natural state, the area would have been dominated by grassland, with an abundance of wetlands and small patches of natural forest. Much of the former grassland area is now occupied by plantation forestry, planted pastures and croplands, while wetlands have been extensively altered by dams. Gum or pine plantations occupy an estimated 10 per cent of the landscape at present and will occupy 20 per cent once the total area for which permits have been allocated have been planted. This can be expected to occur within a relatively short space of time and is thus incorporated into the description of current land use. Beef farming areas are characterised by natural grasslands, but also include Eragrostis curvula pastures. Dairy farming, which uses Friesland cows, is based on planted pastures (mainly ryegrass, as well as kikuyu and $E$. curvula) with maize grown for silage or feed, and natural grasslands. Maize is the main summer grain crop and some wheat is grown during winter (Agricultural census data for 1983, 1993), but production of both summer ( 34000 to $25000 \mathrm{ha}$ ) and winter cereals (800 to 200 ha) decreased slightly between 1983 and 1993 in favour of fodder crops (<50 to $2200 \mathrm{ha}$ ) mainly for dairy farming. Cultivation of seed potatoes is increasing, and there is limited production of oil seeds, legumes, and horticultural products. 


\section{Table 1}

Extent (ha) of protected area and non-protected area in the Underberg magisterial district, and areas of different land uses outside protected areas, calculated as if all areas for which forest permits have been issued are under forestry

\begin{tabular}{|l|c|}
\hline Land Use & Area (ha) \\
\hline Protected Areas & 75011 \\
\hline Total outside protected areas & 120306 \\
\hline Forestry Plantations (full extent of existing permits) & 24560 \\
Dams and wetlands (based Cedara (2001) plus EKZNW (2001)) & 8614 \\
Veld & 69423 \\
Eroded Areas & 2574 \\
Indigenous Forest & 1.4 \\
Cultivated area & 10262 \\
Plantations & 4763 \\
Settlements & 108 \\
\hline Total & 195317 \\
\hline
\end{tabular}

\subsection{Agriculture and forestry}

Beef, dairy and forestry are the predominant production activities in the study area. Beef farming is typically a weaner production system, with herd sizes of about 200-300 breeding cows, and an average stocking rate of 2.2ha. $\mathrm{LSU}^{-1}$ (Stipcich, 2002). Carrying capacity of the natural veld is about 5 ha.LSU ${ }^{-1}$ (Stipcich, 2002). Enterprise profitability determines stock adjustment in the number of breeding animals. Each farm uses about 5-19 labour units (Stipcich, 2002).

The dairy farms keep Friesland cattle which rely almost entirely on irrigated pastures and feed. The stocking rate is about 0.4 ha.LSU ${ }^{-1}$. Dairy farming involves a very high capital outlay.
For example, a milking parlour can cost in the region of R2.4 million. A dairy farm employs more labourers than a beef farm, approximately one labourer per 25 cows.

Timber growers plant pine or gum. Pine plantations are thinned to 40 per cent at about 10-12 years and cleared at $15-17$ years. The rotation for gum is about 7 years. Most of the timber activities (e.g. planting and harvesting) are carried out by contractors. Timber is transported by rail or road to mills. Fire-associated costs (protection, insurance, fire association subs) are the greatest production expense.

The estimated gross income and gross margin for each of the main enterprises of the farms from which financial data were collected are summarised in Table 2.

\section{Table 2}

Estimated average gross margin and net farm income (Rands per ha) for three types of enterprises in the study area based on government enterprise budgets and farm data collected in this study. Capital investment costs of enterprises are taken from Finrec, DoA 1998 data. VAD for forestry is taken from Hassan 2000. All values expressed in 2007 rands.

\begin{tabular}{|l|r|r|r|}
\hline & Beef & Dairy & Forestry \\
\hline Gross income & 657 & 13781 & 1664 \\
Allocated costs & 216 & 4449 & 267 \\
Gross margin & 440 & 9334 & 1398 \\
Overhead costs & 249 & 3594 & 584 \\
\hline Net farm income & 190 & 5741 & 813 \\
\hline
\end{tabular}




\begin{tabular}{|l|r|r|r|}
\hline Capital investment per ha per y for 4-5 years & 21 & 5012 & 105 \\
Tot. investment per ha & 110 & 25058 & 523 \\
Interest payments & 17 & 3960 & 83 \\
NFI net of capital costs & 173 & 1781 & 730 \\
Income per R100 invested & 233 & 31 & 208 \\
\hline Value added to national income & 188 & 5081 & 1587 \\
\hline
\end{tabular}

\subsection{Biodiversity}

The landscape supports rich plant diversity on account of both habitat diversity and within-habitat richness (Hilliard and Burtt, 1987; Pooley, 1998). Approximately 10-20 per cent of the southern Drakensberg is wetland, consisting of oxbow marshes, hillslope seepages and flat hygrophilous grasslands, 80 per cent of the latter having been lost to cropping (Walters et al., 2006). Indigenous grasslands support approximately 15 species $\mathrm{m}^{-2}$, whereas species richness on transformed landscapes has been reduced to as little as $\sim 3$ species $\mathrm{m}^{-2}$ or less (O'Connor, 2003a). Grassland protected for about 50 years supported 78 species $\mathrm{m}^{-2}$. A considerable proportion of plant diversity is found within specific habitats, such as forest patches in protected gorges on southern slopes, drip lines below caves, boulder fields and streams (Hilliard and Burtt, 1987).

Diversity of aculeate wasps and bees fluctuated widely from site to site, but there were very few species (1-4 species per site) in the plantations. Species richness of ants was similar for all natural grassland sites, irrespective of land use. It was considerably reduced in plantations and even more so in cultivated pastures. Ichneumonid wasps showed the opposite trend to that of ants, with the greatest species richness found in plantations and cultivated pastures.

Mountain reedbuck and grey rhebok are South African endemics, whereas oribi is of especial conservation concern in KwaZuluNatal, as populations have declined consistently in recent years on both private and state land (Marchant, 2000). In contrast, reedbuck has flourished in agricultural areas like the southern Drakensberg on account of the availability of high-quality forage during the winter in the form of winter pastures, for instance, rye.
The number of breeding pairs of the Critically Endangered Wattled Crane in the Underberg district declined from 28 in 1982 to eight (of 81 in South Africa) in 2002, mostly as a result of habitat alteration ( $\mathrm{K}$. McCann, Crane Foundation, pers. comm.). A successful breeding site apparently requires wetland surrounded by natural grassland, five of which successful breeding sites were lost directly to dams, while three were lost owing to timber being planted adjacent to the breeding wetland (K. McCann, pers. comm.). In contrast, Crowned Crane increased from 945 in 1980 to \pm 2000 in 2002, of which 430 occurred in the Underberg district. This increase is apparently owing to successful breeding on dairy farms and extensive, year-long use of agricultural lands. Thus the changing landscape has favoured Crowned Crane but has put Wattled Crane at the risk of local extirpation.

\section{6}

\section{Scenario analysis}

\subsection{Description of the scenarios}

The limits to future forestry and agricultural development had to be ascertained before a set of possible future scenarios could be described.

The area for which forestry permits have already been issued covered 13 per cent of the magisterial district or 20 per cent of the area outside the Ukahlamba Drakensberg Park (UDP) (Table 3). This was estimated to result in a reduction of 5 per cent of total runoff or 9 per cent of low flows from the district (Table 3; Appendix 1). 


\section{Table 3}

Percentage area of Underberg district afforested, reduction in total and low flows under different degrees of afforestation. The proportion in parentheses corresponds to the maximum area that could be planted if the 10 per cent restriction applied to low flows.

\begin{tabular}{|l|c|c|c|}
\hline & $\begin{array}{c}\text { Afforested } \\
\text { proportion (\%) }\end{array}$ & $\begin{array}{c}\text { Total flow } \\
\text { Reduction (\%) }\end{array}$ & $\begin{array}{c}\text { Low flow } \\
\text { Reduction (\%) }\end{array}$ \\
\hline Maximum afforestation under existing permits & 13 & 5 & 9 \\
\hline $\begin{array}{l}\text { Maximum afforestation with permits (proportion } \\
\text { allocation and area suitability) }\end{array}$ & $24(14)$ & 10 & $(10)$ \\
\hline Maximum afforestation based on suitable area only & 55 & 22 & 35 \\
\hline
\end{tabular}

It would be feasible to expand forestry to the current legal maximum in terms of the allowed reduction in runoff. If the 10 per cent reduction rule is applied to low flows, there can be very little further development in the area, amounting to a total of 14 per cent coverage of the district. However, if the 10 per cent rule is applied to total runoff, then 24 per cent of the catchment could be afforested.

Without restrictions based on water runoff, but taking other limitations into account (e.g. protected areas, river courses and wetlands), as much as 55 per cent of the district could be planted. This would result in a loss of 22 per cent of total runoff and 35 per cent of low flows (Table 3 ).

The growth of the dairy industry is likely to be limited mainly by economic factors. Soils are not limiting and, based on topographical considerations, it was estimated that the area for cultivation could expand to six times its present area. However, as the dairy industry is limited largely by provincial markets, it was assumed that current needs are supplied and that dairy would not expand at a rate faster than that of regional population growth. We thus estimated that the maximum feasible expansion of dairy in the time period considered would be to triple the existing area.

We assume that cultivation for dairy or cropping is equal in terms of income generated, and we concentrate on expansion of dairy. It is assumed that the outcome would be similar if this represented expansion of other crops instead.

Based on the above findings and assumptions, the six scenarios were quantified in terms of the proportion of different land uses (Table 4).

\section{Table 4}

Description of the scenarios used for comparative analysis, giving percentage area of Underberg district (excluding UDP) of different land uses or habitat types.

\begin{tabular}{|l|c|c|c|c|c|c|}
\hline Land use / habitat & $\begin{array}{c}\mathbf{1 .} \\
\text { All beef } \\
\text { farming }\end{array}$ & $\begin{array}{c}\mathbf{2 .} \\
\text { Present } \\
\mathbf{( 2 0 0 1 )}\end{array}$ & $\begin{array}{c}\mathbf{3 .} \\
\text { Current } \\
\text { permit } \\
\mathbf{( 2 0 0 3 )}\end{array}$ & $\begin{array}{c}\mathbf{4 .} \\
\text { Current } \\
\text { permit + } \\
\text { max dairy }\end{array}$ & $\begin{array}{c}\mathbf{5 .} \\
\text { Max } \\
\text { permit + } \\
\text { max dairy }\end{array}$ & $\begin{array}{c}\text { 6. } \\
\text { unlimited } \\
\text { forest }\end{array}$ \\
\hline Conserved grassland & $1.4 \%$ & $1.4 \%$ & $1.4 \%$ & $1.4 \%$ & $1.4 \%$ & $1.4 \%$ \\
\hline Commercial natural pasture & $93.6 \%$ & $79.0 \%$ & $68.1 \%$ & $58.0 \%$ & $38.0 \%$ & $0.0 \%$ \\
\hline Planted pasture \& feed crops & $0.0 \%$ & $4.9 \%$ & $4.9 \%$ & $15.0 \%$ & $15.0 \%$ & $2 \%$ \\
\hline Crops & $0.0 \%$ & $0.3 \%$ & $0.3 \%$ & $0.3 \%$ & $0.0 \%$ & $0.0 \%$ \\
\hline Plantation forest & $0.0 \%$ & $9.1 \%$ & $20.0 \%$ & $20.0 \%$ & $40.0 \%$ & $91.0 \%$ \\
\hline Dams & $0.5 \%$ & $1.1 \%$ & $1.1 \%$ & $1.8 \%$ & $1.8 \%$ & $0.2 \%$ \\
\hline Wetlands & $4.8 \%$ & $4.2 \%$ & $4.2 \%$ & $3.5 \%$ & $3.5 \%$ & $5.1 \%$ \\
\hline
\end{tabular}




\section{7 \\ Results}

\subsection{Biophysical impacts}

Increasing development in the study area is likely to have significant impacts on biodiversity. For indigenous plants, average alpha diversity (species richness at a local level) is already estimated to have declined to about 86 per cent of the reference condition for the area (Table 5). With full use of current forestry permits, it is estimated to decline further ( 78 per cent), while future development scenarios 4-6 may result in average alpha diversity dropping to 67 per cent,
50 per cent and 20 per cent of original levels, respectively (Table 5). It is difficult to estimate how this would translate to a loss of species from the study area as a whole, seeing that the population dynamics of these plant species are not well known. However, professional opinion suggests that about 10 species could already have been lost from the district, while up to 70 species could be lost in scenario 6. Changes in the number of weed species are not considered, but further forestry development could result in an increase in the cover of American Bramble from 12 per cent at present to 22 per cent in scenario 5 and as much as 40 per cent under scenario 6 (Table 5).

Table 5

Estimated biodiversity impacts of different land use scenarios for Underberg district

\begin{tabular}{|c|c|c|c|c|c|c|}
\hline & $\begin{array}{c}1 . \\
\text { All beef } \\
\text { farming }\end{array}$ & $\begin{array}{c}2 . \\
\text { Present } \\
(2001)\end{array}$ & $\begin{array}{c}3 . \\
\text { Current } \\
\text { permit } \\
(2003)\end{array}$ & $\begin{array}{c}4 . \\
\text { Current } \\
\text { permit + } \\
\text { max dairy }\end{array}$ & $\begin{array}{c}5 . \\
\text { Max } \\
\text { permit }+ \\
\text { max dairy }\end{array}$ & $\begin{array}{l}\text { 6. Max } \\
\text { unlimited } \\
\text { forest }\end{array}$ \\
\hline \multicolumn{7}{|l|}{ Plants } \\
\hline Indigenous species per $160 \mathrm{~m}^{2}$ plot & 76 & 66 & 59 & 51 & 38 & 15 \\
\hline Weed species per $160 \mathrm{~m}^{2}$ plot & 5 & 5 & 5 & 5 & 5 & 5 \\
\hline$\%$ area bramble & 9.5 & 12.2 & 15.8 & 15.0 & 21.7 & 39.5 \\
\hline \multicolumn{7}{|l|}{ Invertebrate species } \\
\hline Ant spp. per ha & 23 & 21 & 19 & 17 & 15 & 10 \\
\hline Total ant spp. & 60 & 60 & 60 & 60 & 59 & 59 \\
\hline Vulnerable ants & 7 & 6 & 5 & 4 & 3 & 0 \\
\hline \multicolumn{7}{|l|}{ Bird species } \\
\hline Wattled Crane (pairs) & 28 & 8 & 7 & 5 & 3 & 0 \\
\hline Crowned Crane (number) & 300 & 431 & 431 & 583 & 583 & 244 \\
\hline \multicolumn{7}{|l|}{ Mammal populations } \\
\hline Mountain Reedbuck & 482 & 409 & 355 & 304 & 204 & 14 \\
\hline Grey Rhebok & 482 & 409 & 355 & 304 & 204 & 14 \\
\hline Reedbuck & 1446 & 1297 & 1188 & 1087 & 887 & 507 \\
\hline Oribi & 964 & 818 & 709 & 608 & 408 & 28 \\
\hline
\end{tabular}

While the different land-use scenarios would not affect invertebrate species richness at the regional level, with all but one ant species surviving scenarios 5 and 6 , the local diversity of ants would be expected to decline with increasing levels of development. The populations of certain vulnerable ant species could decline markedly (Table 5).
Though none would become extinct in the medium term, the populations of the four mammal species considered would be negatively affected by increasing agricultural and forestry development. Three of these species could decline to levels that might jeopardize long-term survival. This includes oribi, which are also rare 
on a broader scale. Their overall survival would thus be affected (Table 5).

The dramatic reduction of the Wattled Crane population would continue with increased development, probably reaching extinction under scenario 6 (Table 5). Their future long-term survival is already threatened and risks of extinction will be exacerbated by any further development. Given past trends, it is anticipated that the population of Crowned Cranes could increase by about 100 birds under scenarios 4 and 5, but an extreme afforestation scenario is likely to reduce the population to below that of the original condition.

Afforestation to the full extent of current permits will result in a significant reduction of water runoff. The study area will have undergone significant losses of water runoff due to forestry by the time the current permits have been fully utilised. In addition, the creation of dams has already led to comparable water losses (Table 6). Evaporative losses due to irrigation are comparatively minor. With increasing crop and tree cultivation, soil losses are expected to reach as much as 88000 tons under plausible future scenarios, far more than if forestry expansion remained unchecked (Table 6). Carbon sequestration, on the other hand, increases with increasing forestry development, with negligible long-term sequestration in natural grasslands, but as much as 132000 and 279000 tons being sequestered annually in scenarios 5 and 6 . This is a major increase compared with the present and near-future situation (Table 6).

\section{Table 6}

Physical impacts of different land use scenarios for Underberg district

\begin{tabular}{|l|c|c|c|c|c|c|}
\hline & $\begin{array}{c}\mathbf{1 .} \\
\text { All beef } \\
\text { farming }\end{array}$ & $\begin{array}{c}\mathbf{2 .} \\
\text { Present } \\
\mathbf{( 2 0 0 1 )}\end{array}$ & $\begin{array}{c}\text { 3. } \\
\text { Current } \\
\text { permit } \\
(\mathbf{2 0 0 3})\end{array}$ & $\begin{array}{c}\mathbf{4 .} \\
\text { Current } \\
\text { permit }+ \\
\text { max dairy }\end{array}$ & $\begin{array}{c}\text { Max } \\
\text { permit }+ \\
\text { max dairy }\end{array}$ & $\begin{array}{c}\text { Max. } \\
\text { unlimited } \\
\text { forest }\end{array}$ \\
\hline Water losses forestry $\left(\mathrm{Mm}^{3}\right)$ & 0 & 11 & 21 & 21 & 28 & 93 \\
\hline Evaporative losses dams $\left(\mathrm{Mm}^{3}\right)$ & 8 & 19 & 19 & 30 & 30 & 4 \\
\hline Evap losses irrigation $\left(\mathrm{Mm}^{3}\right)$ & - & 0.0004 & 0.0004 & 0.0012 & 0.0012 & 0.0002 \\
\hline Soil losses (tons.y $\left.{ }^{-1}\right)$ & - & 29.900 & 40.800 & 69.200 & 88.000 & 97.400 \\
\hline Carbon sequestration (tons.y $\left.{ }^{-1}\right)$ & 15.198 & 41.248 & 72.640 & 74.014 & 131.614 & 278.812 \\
\hline
\end{tabular}

\subsection{Economic implications}

The relative economic value of the alternative scenarios, taken from a societal perspective, includes the direct values accruing primarily at the local level and the indirect, option and non-use values of the area that accrue on a broader scale. Direct use value from agricultural and forestry activities increases with increasing development, while value from activities reliant on natural habitats, such as tourism and natural resource harvesting, decrease. The latter values are much too small to significantly offset the overall trend of increasing economic value (Figure 2). Direct use value could increase by some $\mathrm{R} 48 \mathrm{~m}$ per year if development moves from scenarios 3 to 4 , and by a further $\mathrm{R} 21 \mathrm{~m}$ from scenarios 4 to 5 .

The value of carbon sequestration increases with increasing afforestation, to a maximum of R29.5 million per year in scenario 6 (Figure 2). This is significant in terms of the magnitude of direct use values discussed above. However, by far the greatest value of the area is the indirect value of water runoff, worth over R900 million in scenario 1. 

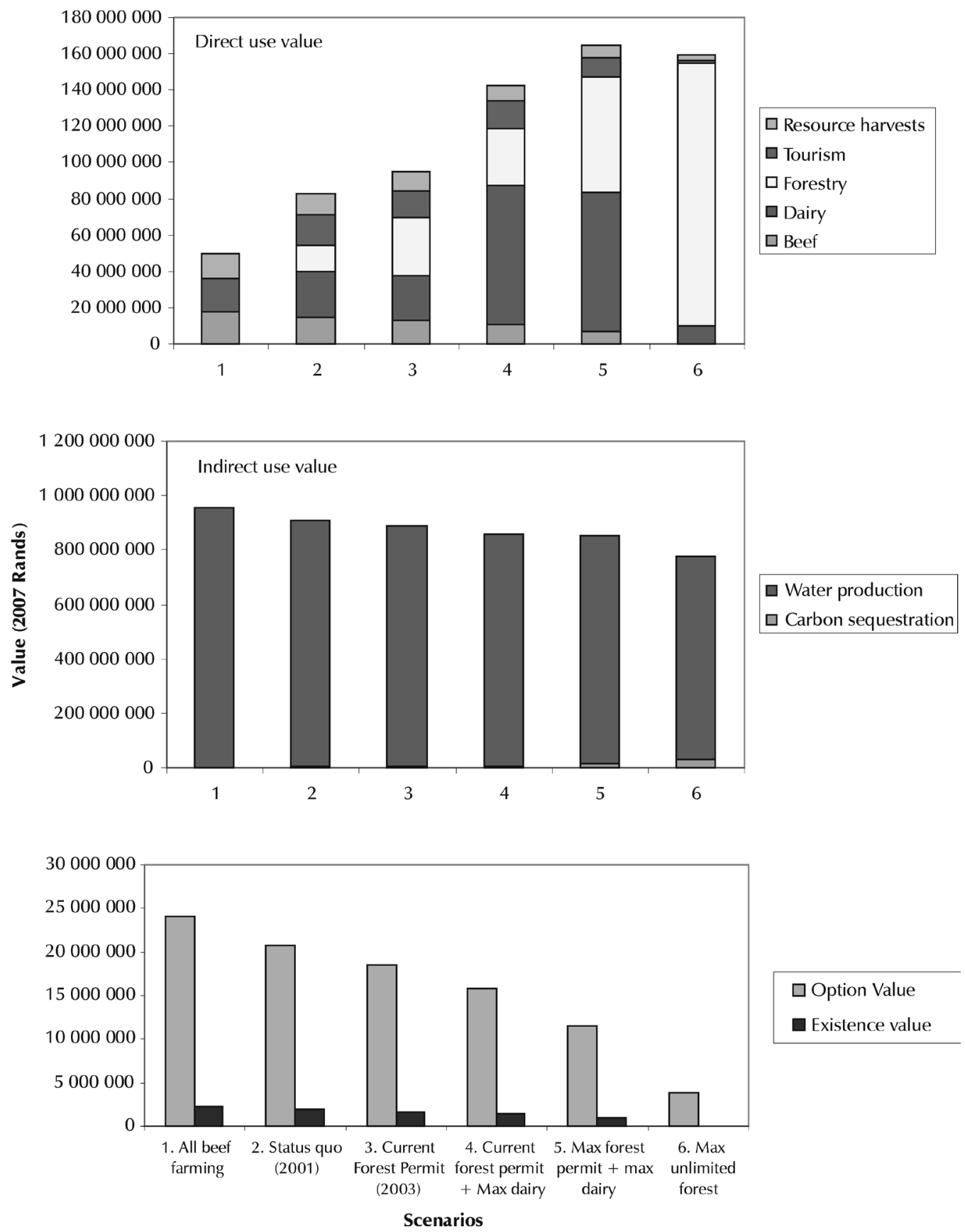

Figure 2

Estimated direct use values, indirect use values, option value and existence value of the area under different scenarios in terms of value added to the economy, 2007 rands. Note that the option value is partial (immediate potential use of animals and plants) and does not include future potential exploitation of genetic diversity. 
Option value, partially estimated here as the value of potential harvests, is fairly substantial compared to farming values (Figure 2), but decreases as natural habitats are reduced by agricultural and forestry development. Existence value, also strongly tied to natural habitats, is smaller than option value (Figure 2). This is a highly conservative assumption of existence value. However, given the large area of similar landscape in the province, plus the large area already protected, it is unlikely that public willingness to pay for the protection of these areas is high when considered at the local scale.

If the above values are aggregated, and soil losses (which range up to over R6.5 million per year for scenarios 5 and 6 ) are subtracted from overall indirect-use value, the gains from development are closely balanced by the losses in biodiversity-related values (Figure 3). While there is a decreasing trend in total economic value from scenarios 1 to 3 , the results suggest that further development up to scenario 5 would yield an overall economic gain. However, the gain from scenarios 3 to 4 is some R16 million, and from 4 to 5 would be about R6.7 million. Taking into consideration possible errors in estimation, as well as the fact that the biodiversity values, particularly option and existence value, have been conservatively estimated, it cannot be concluded that further development would be beneficial. The main conclusion here is that the costs of agricultural and forestry development in terms of biodiversity losses are sufficiently high to possibly outweigh the benefits.

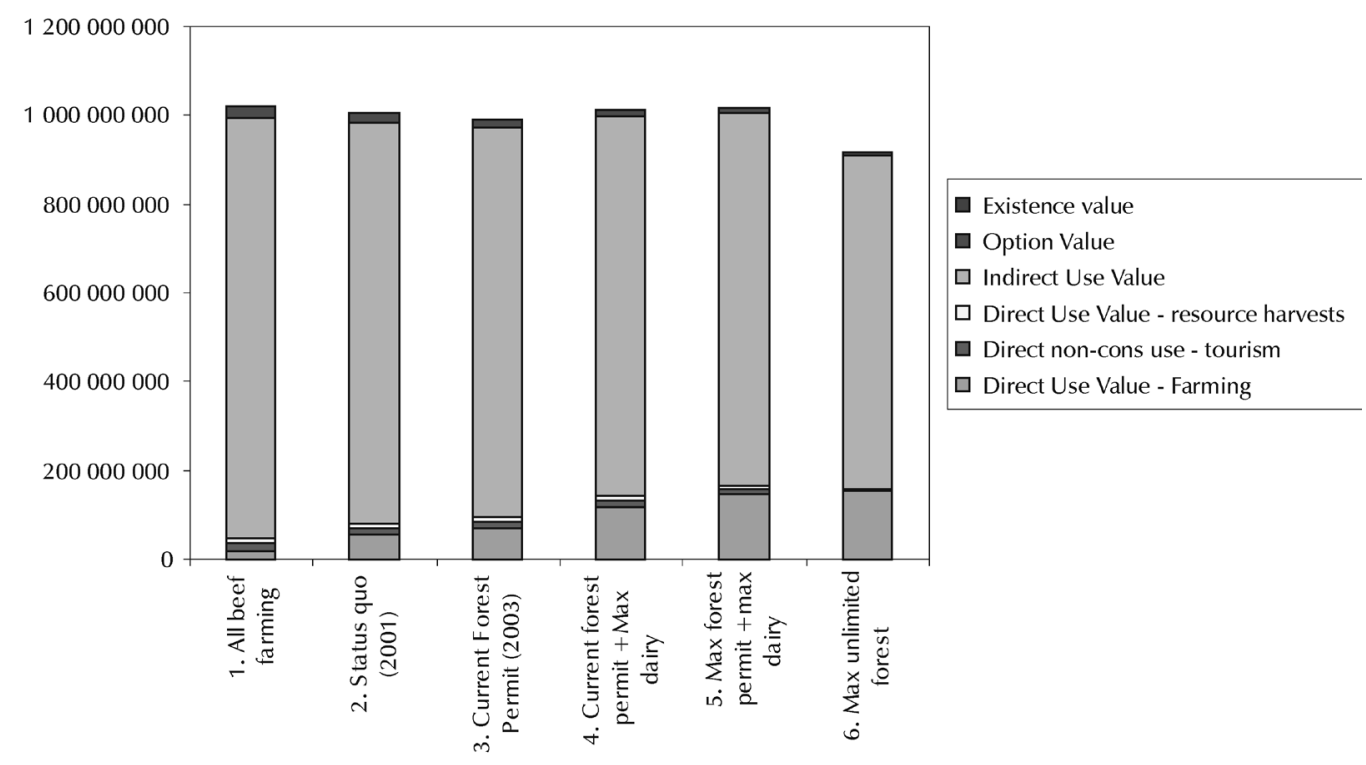

Figure 3

Partial estimate of the total economic value of Underberg district resources fewer than six land-use scenarios. Indirect use value is primarily the value of water runoff. Note that the estimation does not account for contribution to downstream aquatic goods and services, and estimates of option and existence value are partial. Values in 2007 rands.

8

\section{Discussion and conclusions}

There has already been significant transformation of the Sourveld grasslands and the associated habitats of the Underberg district. This has accelerated over the past decade, but it can be expected that the rate of change will slow down as allowable and suitable areas for expansion of forestry and dairy become saturated. Nevertheless, over the medium to long term, a substantial change in land cover 
can be expected. This study also considered a situation of unrestricted expansion of forestry into economically viable growing areas. This was merely to illustrate an extreme case, as the situation is unlikely to arise in reality. On the contrary, rules governing agricultural and forestry expansion may become more restrictive as environmental concerns become increasingly recognised in national policy.

Changing land use to dairy, forestry or other crops leads to a direct loss of natural grassland and associated wetlands, as well as to invasion of these habitats by alien plant species. The loss and fragmentation of habitats will result in population decline and loss of diversity at the local and, possibly, the regional level. An obvious question is whether concern about biodiversity conservation in these areas is necessary, when the Ukhahlamba Drakensberg Park (UDP) is going to assure the persistence of much of the area's biodiversity. However, the UDP does not cater adequately for some habitats (notably wetlands) and several red data species, nor does it contain the undulating landscapes of the agricultural districts.

Conservation arguments alone do not hold up against a national goal of increasing overall economic welfare. This study has therefore attempted to evaluate the economic impacts of the increasing transformation of these habitats, accounting for biodiversity impacts. The main conclusion of this study is that development of grasslands will yield considerable economic benefits, but at a significant environmental cost, which is large enough to rival expected benefits. Nevertheless, it should be noted that many of the estimates and assumptions are rough. For example, it was assumed that the impact on tourism value would be negative and proportional to the area of plantation forestry, because most tourism is nature-based. However, tourism tastes change to suit changing environments.

The findings suggest that the initial conversion from a predominantly grassland area to the recent state of affairs has been the most costly in terms of environmental values, and that the imminent transformation to scenario 3 will also incur a large net cost. Since many other areas outside the study area are in a rapid phase of transition, and some are undoubtedly still less developed than the Underberg district, it is important to take note of these impacts for planning on the regional scale.

Timber growing in particular carries large externalities: Not only does it lead to reduction in the quantity and quality of catchment runoff, but also to a loss of habitat. Indeed, areas suitable for forestry coincide with the preferred habitat of the increasingly rare oribi. The main mode of transformation at present is from beef to timber. Growth in the dairy sector can be expected to be much slower, for two reasons. First, the majority of suitable land is already under dairy, and, second, the market is a limiting factor. Dairy is dominated by a few large-scale farmers, and any increase is mainly due to expansion of existing operators; change in land use might occur if a dairy farmer were to buy out an adjacent beef farmer.

If further land-use intensification is suboptimal from both an ecological and economic perspective, why does it occur and how can it be discouraged? The change from beef to timber is being driven by an increasing difference in income from the two activities. Returns from timber have been improving with growing global demand and have also been improved by depreciation of the rand. In contrast, returns from beef farming are decreasing with increasing stock theft. Army patrols kept theft levels down for four years up to April 2002, but theft reportedly increased thereafter, causing forestry to become more attractive simply from the risk perspective. In addition, timber growing involves use of contractors rather than management permanent labourers, and this is a significant incentive in the light of developments in labour law. Indeed, the latter issue is probably one factor, along with capital start-up costs, discouraging rapid expansion of dairy farming, which is relatively labour intensive. Not only are farm owners converting to timber, but many are selling to large-scale timber growers who may buy up to 50 farms (John Banach, Dept. Economics, UNP, pers. comm.). Farmers' propensity to sell has probably increased owing to the social changes described above, a decline in income, and the farmers' reluctance to change what they farm. 
Given the private incentive for conversion, the only way to discourage it is through active reversal of incentives. This may simply require corrections of market failure by internalising the externalities associated with forestry and dairy. In theory, both industries should be subject to levies that cover the damages caused by their activities. This would decrease the financial returns involved. For example, income from beef farming could be increased by means of effective patrols or mechanisms to reduce the rate of stock theft. In addition, encouragement of naturebased tourism with targeted marketing efforts, for instance, would provide further incentive for landowners to maintain their grasslands. All of these actions would be possible only if there were to be policy changes on the basis of the economic arguments presented above.

Finally, it should also be noted that this paper has not considered the potential scenario of restrictions on certain land uses leading to reduced property values and land acquisition by government for resettlement. In other words, policy actions to curb land uses leading to biodiversity loss could fail to achieve conservation goals if they inadvertently lead to other forms of land use. This aspect deserves further research.

\section{9}

\section{Acknowledgements}

This research was carried out as part of the GEF-funded Conservation Farming Project of the South African National Botanical Institute. Thanks to Danette Stipcich, Conrad Savy, Myles Mander and Mphoya Thobela for their inputs and to two anonymous referees for comments on the manuscript.

\section{0}

\section{References}

1 CHRISTIE, S.I. \& SCHOLES, R.J. (1995)

"Carbon storage in eucalyptus and pine plantations in South Africa", Environmental Monitoring and Assessment, 38: 231-241.

2 CONNINGARTH CONSULTANTS (2003) Thukela Reserve Study - Resource Economics.
3 CSIR (2001) "Water resource accounts for South Africa 1991-1998", Report No. ENV-P-C 2001-050 Environmentek, CSIR: Pretoria.

4 DE WIT, M.P.; CROOKES, D.J. \& VAN WILGEN, B.W. (2003) "Conflicts of interest in environmental management: Estimating the costs and benefits of black wattle (Acacia mearnsii) in South Africa”, Biological Invasions, 3(2): 167-178.

5 DOA (Department of Agriculture) (1987) Census of Agriculture Provincial Statistics 1983, KwaZuluNatal, Statistics South Africa: Pretoria.

6 DOA (1992) Census of Agriculture Provincial Statistics 1988, KwaZulu-Natal, Statistics, South Africa: Pretoria.

7 DOA (1997) Census of Agriculture Provincial Statistics 1993, KwaZulu-Natal, Statistics South Africa: Pretoria.

8 DWAF (Department of Water Affairs and Forestry) (1999) Water-Use Licensing: The Policy and Procedure for Licensing Stream Flow Reduction Activities (Final Draft), DWAF: Pretoria.

9 FAIRBANKS, D.H.K. \& SMITH, R.E. (1995) "Report and maps on the afforestation potential land evaluation of the Northern Province, Western Cape Province, Ciskei and Transkei”, Report. FORDEA No 940, Forestek, CSIR: Pretoria.

10 GITTINGER, J.P. (1982) Economic Analysis of Agricultural Projects, Johns Hopkins University Press: Baltimore.

11 GUSH, M.B.; SCOTT, D.F.; JEWITT, G.P.W.; SCHULZE, R.E.; HALLOWES, L.A. \& GÖRGENS, A.H.M. (2002a) "A new approach to modelling streamflow reductions resulting from commercial afforestation in South Africa", South African Journal of Forestry, 196:27-36.

12 GUSH, M.B.; SCOTT, D.F.; JEWITT, G.P.W.; SCHULZE, R.E.; LUMSDEN, T.; HALLOWES, L.A. \& GÖRGENS, A.H.M. (2002b) "Estimation of streamflow reductions resulting from commercial afforestation in South Africa", Water Research Commission Report TT173/02.

13 HASSAN, R.M. (2000) "Improved measure of the contribution of cultivated forests to national income and wealth in South Africa", Environment and Development Economics, 5: 157-176.

14 HILLIARD, O.M. \& BURTT, B.L. (1987) The Botany of the Southern Natal Drakensberg, National Botanic Gardens: Cape Town.

15 IPCC/OECD (Intergovernmental Panel on Climate Change/Organization for Economic Co-operation and Development) (1994) Joint Programme, IPCC Draft Guidelines for National Greenhouse Gas Inventories, IPCC/OECD Joint Programme, Paris. 3 Volumes. 
16 KING, N.A. \& CRAFFORD, J.G. (2001)

"Towards water resource accounts for South Africa for the period 1991 to 1998", Agrekon 40 (4): 1-17.

17 KOTZE, D.C. \& O'CONNOR, T.G. (2003) "Impact of land use on community organisation and ecosystem functioning of wetlands in the southern Drakensberg mountains, South Africa”, Conservation Farming Project Report to National Botanical Institute.

18 LE MATIRE, D.C.; VAN WILGEN, B.W.; CHAPMAN, R.A. \& MCKELLY, D.H.1. (1996)

"Invasive plants and water resources in the Western Cape Province, South Africa: modelling the consequences of a lack of management", Journal of Applied Ecology, 33: 161-172.

19 MARCHANT, A.N. (2000) "The status of oribi (Ourebia ourebi) on private land and nature reserves in KwaZulu-Natal, South Africa, since 1981", Lammergeyer, 45: 70-74.

20 METROPLAN (2001) A Special Case Area Plan for the Drakensberg, The Town and Regional Planning Commission: Pietermaritzburg.

21 MILLS, A.J. (2003) "Reciprocal relationships between vegetation structure and soil properties in selected biomes of South Africa", PhD thesis, University of Stellenbosch, December.

22 NATHAN ASSOCIATES (2001) "Carbon sinks - a rehabilitation option for South Africa's natural environment", Vol. II. Transkei carbon sink options and related costs and benefits, unpublished report. $58 \mathrm{pp}$.

23 NORDHAUS, W.D. (1994) Managing the Global Commons, MIT Press: Cambridge, MA.

24 O'CONNOR, T.G. (2003a) "Influence of land-use on plant community composition and diversity in Highland Sourveld grassland in the southern Drakensberg, South Africa”, Conservation Farming Project Report to National Botanical Institute.

25 O'CONNOR, T.G. (2003b) "Distribution and abundance of two alien invasive plant species in the southern Drakensberg", Conservation Farming Project Report to National Botanical Institute.

26 O'CONNOR, T.G. (2004) "Influence of land use on populations of the medicinal plant Alepidea amatymbica in the southern Drakensberg", South African Journal of Botany, 70: 319-322.

27 O'CONNOR, T.G. "Influence of land use on phytomass accumulation in Highland Sourveld grassland in the southern Drakensberg, South Africa", African Journal of Range and Forage Science (in press).

28 O'CONNOR, T.G. \& BREDENKAMP G.J. (1997) "Grassland", in Cowling R.M., Richardson D.M. \& Pierce S.M. (eds.) Vegetation of South Africa, Cambridge University Press: Cambridge.
29 O'CONNOR, T.G. \& KRUGER, S. (2003)

"Synchronous decline of populations of small antelope in a reserve in the southern Drakensberg, South Africa. South African Journal of Wildlife Research 33: 97-107.

30 O'CONNOR, T.G. \& MILLS, A.J. (2003) "Influence of land use on nutrient stocks in the montane grassland of the southern Drakensberg, South Africa”, Conservation Farming Project Report to National Botanical Institute.

31 POOLEY, E. (1998) A Field Guide to Wild Flowers KwaZulu-Natal and the Eastern Region, Natal Flora Publications Trust: Durban.

32 REBELO, A.G. (1997) "Conservation", in R.M. Cowling, D.M. Richardson \& S.M. Pierce (eds.) Vegetation of Southern Africa, Cambridge University Press: Cambridge, pp 571-590.

33 ROBERTSON, H. \& VAN NOORT, S. 2003. Effects of agricultural practices on ants and other Hymenoptera in four farming areas of South Africa. Conservation Farming Project Report to National Botanical Institute.

34 ROWLANDS, I. (1996) "Going with the floe: South Africa and global climate change", Social Policy Series, Policy: Issues and Actors 9(2), Centre for Policy Studies, London School of Economics and Political Science: London.

35 SCHOLES, B. \& VAN DER MERWE, M. (1995)

"South African green house inventory", CSIR Report FOR-DEA 918, CSIR: Pretoria.

36 SCHULZE, R.E. (1997) South African Atlas of Agrohydrology and climatlogy, Water Research Commission, Pretoria, Report TT82/96.

37 SCOTT, D.F. \& SMITH, R.E. (1997) "Preliminary empirical models to predict reductions in total and low flows resulting from afforestation", Water $S A$, 23: $135-140$.

38 SCOTT, D.F.; LE MAITRE, D.C. \& FAIRBANKS, D.H.K. (1998) "Forestry and streamflow reductions in South Africa: a reference system for assessing extent and distribution", Water SA, 24: 187-199.

39 SCOTT-SHAW, R. (1999) Rare and Threatened Plants of KwaZulu-Natal and Neighbouring Regions, KwaZulu-Natal Nature Conservation Service: Pietermaritzburg.

40 SHORT, A.D.; O'CONNOR, T.G. \& HURT, C.R. (2003) "Medium-term changes in grass composition and diversity of Highland Sourveld grassland in the southern Drakensberg in response to fire and grazing management", African Journal of Range \& Forage Science, 20: 1-10.

41 STIPCICH, D. (2002) "Economic survey, Underberg/Himeville", NBI Conservation Farming Project. 
42 TURPIE, J.K., WINKLER, H. \& MIDGLEY, G. (2004) "Economic impacts of climate change in South Africa: a preliminary analysis of unmitigated damage costs.” Pp. 130-160 in: Blignaut, J.N. \& de Wit, M.P. Sustainable Options. UCT Press.

43 TURPIE, J.K. (2003) "The existence value of biodiversity in South Africa: how interest, experience, knowledge, income and perceived level of threat influence local willingness to pay", Ecological Economics, 46: 199-216.

44 VAN WILGEN, B.W.; DE WIT, M.P.; ANDERSON, H.J.; LE MAITRE D.C.; KOTZE, I.M.; NDALA, S.; BROWN, B. \& RAPHOLO, M.B. (2004) "Costs and benefits of biological control of invasive alien plants: case studies from South Africa”, South African Journal of Science, 100: 113-122.

45 WALTERS, D.J.; KOTZE, D.C. \& O'CONNOR, T.G. (2006) "Impact of land use on vegetation composition, diversity, and selected soil properties of wetlands in the southern Drakensberg mountains, South Africa”, Wetlands Ecology and Management, 14: 329-348.

46 WILDY, E.J. (2003) "Effect of different land use practices on invertebrate diversity in Underberg, KwaZulu-Natal, South Africa", Conservation Farming Project Report to National Botanical Institute.

\section{Personal communications:}

Jake Alletson, PO Box 1129, Hilton, 3245.

Chris Davel, DWAF, DWAF, Private Bag X313, Pretoria 0001.

D. Leighme, Cedara, Department of Agriculture, Pietermaritzburg.

W. Pitchford, ex Working for Water, Private Bag X4390, Cape Town 8000, South Africa

K. McCann, Crane Foundation, pers. comm. KZN Crane Foundation, PO Box 905, Mooi River 3300. John Banach, Dept. Economics, University of Natal, Pietermaritzburg.

\section{Appendix 1}

In order to estimate the percentage reduction in runoff from a catchment, runoff reduction figures yielded by the model in $\mathrm{m}^{3}$ were converted to $\mathrm{mm}$ using the following equality:

$\frac{\text { Runoff }\left(m^{3} / h a\right)}{10}=$ Runoff $(\mathrm{mm})$.

Percentage reduction for a quaternary catchment $\left(\% \mathrm{R}_{\mathrm{q}}\right)$ was then calculated using DWAF's formula:

$\% R_{q}=\frac{M L F R_{i}}{A M L F} \times \frac{A_{f}}{A_{q}}$

where $M_{L F R}{ }^{\mathrm{i}}=$ median annual low flow reduction for species $\mathrm{i}, \mathrm{AMLF}=$ median annual low flow based on Acock's baseline vegetation on medium soils for that catchment, $A_{f}=$ the afforested area, and $\mathrm{A}_{\mathrm{q}}$ is the area of the quaternary catchment.

The percentage reduction in runoff for Underberg district was estimated as follows:

$\% R_{U}=\frac{\sum_{q=1}^{13} B_{q} \cdot P Q_{q}}{\sum_{q=1}^{13} R_{q}} \times \frac{A_{f U}}{A_{U}}$,

where $\mathrm{B}_{\mathrm{q}}=$ baseline flow $(\mathrm{mm}), \mathrm{PQ}_{\mathrm{q}}=$ percentage of catchment $\mathrm{q}$ in Underberg district, $\mathrm{R}_{\mathrm{q}}=$ runoff reduction for catchment $\mathrm{q}, \mathrm{A}_{\mathrm{fU}}=$ area of forest in Underberg, $\mathrm{A}_{\mathrm{U}}=$ area of Underberg. 